\title{
Perilaku Peternak Sapi Potong di Era New Normal Covid-19 Terhadap Penerapan Biosekuriti di Nusa Tenggara Barat
}

\author{
Behavior of Beef Cattle Farmers in the New Normal Era of Covid-19 \\ Towards the Implementation of Biosecurities in Nusa Tenggara Barat
}

\author{
Mashur \\ Program Studi Pendidikan Dokter Hewan, \\ Universitas Pendidikan Mandalika Mataram, Nusa Tenggara Barat \\ *E-mail: mashur@undikma.ac.id
}

\begin{abstract}
ABSTRAK
Penelitian ini bertujuan untuk mengetahui perilaku peternak sapi potong pada peternakan rakyat di Era New Normal Covid-19. Penelitian dilakukan di 10 Kabupaten/Kota di Provinsi Nusa Tenggara Barat pada bulan Maret - Mei 2021. Metode penelitian yang digunakan adalah survei melalui wawancara menggunakan questioner yang dikirim melalui Whatsapp mahasiswa Fakultas Kedokteran Hewan Undikma yang sedang berada di desa masing - masing pada program work from home. Data dianalisis secara deskriptif dengan menggunakan tabel distribusi frekuensi. Hasil penelitian menunjukkan bahwa berdasarkan indikator pernyataan sikap, norma subyektif dan kontrol perilaku peternak sapi potong pada peternakan rakyat di Era New Normal Covid-19 di Nusa Tenggara Barat terhadap penerapan biosekuriti memperoleh nilai 3.301 yang berada pada interval 3.063 - 3.783. Berdasarkan nilai tersebut dapat disimpulkan bahwa peternak sapi potong pada peternakan rakyat di Nusa Tenggara Barat setuju terhadap penerapan biosekuriti pada peternakan rakyat sapi potong di Era New Normal Covid-19.
\end{abstract}

Kata Kunci: Biosekuriti, New Era Covid-19, Perilaku, Sapi Potong

\begin{abstract}
This study aims to determine the behavior of beef cattle farmers on smallholder farms in the New Normal era of Covid-19. The research has been conducted in 10 regencies/cities in West Nusa Tenggara Province in March-May 2021. The research method used is a survey with interviews using questionnaires sent via WhatsApp for students of the Faculty of Veterinary Medicine Undikma who are in their respective
\end{abstract}


villages on the work from home program. The data were analyzed descriptively by using a frequency distribution table. The results showed that based on indicators of attitude statements, subjective norms and behavioral control of beef cattle breeders on smallholder farms in the New Normal Covid-19 Era in West Nusa Tenggara towards the implementation of biosecurity, a value of 3,301 was obtained which was in the interval of 3,063-3,783. Based on this value, it can be concluded that beef cattle breeders on smallholder farms in West Nusa Tenggara agree to the implementation of biosecurity on smallholder beef cattle farms in the New Normal Era of Covid-19.

Keyword: Beef Cattle, Behavior, Biosecurity, New Era Covid-19

\section{PENDAHULUAN}

Pandemik Covid-19 telah melanda hampir seluruh aspek kehidupan manusia di seluruh dunia termasuk perilaku peternak sapi potong terhadap penerapan biosekuriti pada peternakan rakyat di Nusa Tenggara Barat. Ajzen (1991) menyatakan bahwa dalam teori perilaku terencana (Theory of planned behaviour) perilaku seseorang akan muncul karena adanya niat untuk berperilaku. Niat seseorang untuk berperilaku dapat diprediksi melalui tiga hal, yaitu sikap terhadap perilaku (attitude toward the behavior), norma subyektif (subjective norm), dan persepsi pengendalian diri (perceived behavioral control). Ada empat elemen utama yang digunakan untuk pengukuran niat individu untuk berperilaku yaitu target dari perilaku yang dituju (target), tindakan (action), situasi pada saat perilaku ditampilkan (contex), dan waktu pada saat perilaku ditampilkan (time) (Ajzen, 2006).
Penerapan biosekuriti adalah salah satu kebijakan pemerintah yang tertuang pada pasal 36 Peraturan Pemerintah RI Nomor 47 tahun 2014 tentang Pengendalian dan Penanggulangan Penyakit Hewan, Hal ini dimaksudkan untuk mendukung peternakan sapi potong di Indonesia, karena biosekuriti merupakan strategi dalam pencegahan penyakit menular dari ternak ke ternak atau dari ternak ke manusia. Biosekuriti dapat dilakukan melalui sanitasi, isolasi dan kontrol lalu lintas (Direktorat Jenderal Peternakan dan Kesehatan Hewan, 2014). Penerapan biosekuriti yang buruk pada peternakan rakyat dapat mempengaruhi produktivitas sapi potong. Bonanno (2011) melaporkan bahwa kasus penyakit digital dermatitis (hairy heel wrats), haemorrhagic bowel syndrome (HBS), dan acute bovine liver disease (ABLD) pada suatu peternakan sapi terjadi akibat penerapan biosekuriti yang buruk. Penyakit ini disebabkan oleh sistem drainase yang buruk, sanitasi dan hygiene yang 
buruk, kondisi pakan yang tidak baik, serta kondisi kelembaban di dalam kadang yang buruk. Hasil penelitian Mashur et al. (2020) menunjukkan bahwa tingkat penerapan manajemen kesehatan sapi potong pada peternakan rakyat berbasis kandang kolektif di Pulau Lombok berdasarkan persyaratan teknis dan kesehatan kandang serta pengelolaanya berada pada interval nilai cukup.

Tingkat penerapan biosekuriti yang buruk diduga dipengaruhi oleh perilaku peternak sapi potong. Pandemik Covid-19 juga berdampak terhadap perubahan perilaku peternak sapi potong pada peternakan rakyat. Penurunan produksi pada masa pandemi Covid-19 disebabkan karena dampak tidak langsung dari kebijakan Pembatasan Sosial Berskala Besar (PSBB). Untuk menghindari peluang tertular Covid-19, peternak tidak mencari rumput secara maksimal sesuai kebutuhan, tetapi hanya mencari seadanya di sekitar rumah. Akibatnya, produktivitas sapi menurun (Ilham dan Haryanto, 2020). Status keberlanjutan perbaikan manajemen pakan, air minum dan social ekonomi dan budaya pada peternakan rakyat sapi potong berbasis kandang kolektif di Pulau Lombok berada pada kategori cukup berkelanjutan dengan tiga strategi perbaikan yang direkomendasikan, yaitu: (1) strategi peningkatan produktivitas, efisiensi dan pendapatan peternak; (2) strategi peningkatan peran pemerintah, dunia usaha dan stake holder lainnya dan (3) strategi penguatan kelembagaan tani, kelembagaan ekonomi petani, kelembagaan penyuluhan dan peran tokoh masyarakat (Mashur, 2021)

Mengingat pentingnya peranan biosekuriti sebagai benteng pertama dalam usaha pencegahan penyakit maka telah dilakukan penelitian dengan tujuan untuk mengetahui perilaku peternak sapi potong pada peternakan rakyat terhadap penerapan biosekuriti di Era New Normal Covid-19 di Nusa Tenggara Barat. Berdasarkan latar belakang tersebut maka ditetapkan rumusan masalah penelitian bagaimana perilaku peternak sapi potong di Era New Normal Covid-19 terhadap penerapan biosekuriti pada peternakan rakyat di Nusa Tenggara Barat.

\section{MATERI DAN METODE}

Penelitian dilakukan di 10 Kabupaten/Kota di Provinsi Nusa Tenggara Barat pada bulan Maret - Mei 2021. Jumlah peternak sapi potong yang dijadikan sebagai responden sebanyak 36 orang yang ditentukan secara purposive random sampling. Responden berasal dari 36 desa domisili mahasiswa Fakultas Kedokteran Hewan Universitas Pendidikan Mandalika Mataram yang sedang berada di desa masing-masing pada program work from home(WFH) di Era New Normal Covid-19. Kriteria responden adalah telah memiliki pengalaman memelihara 
sapi potong minimal dua tahun dan bersedia diwawancarai. Pengumpulan data dilakukanoleh mahasiswa dengan wawancara menggunakan questioner yang dikirim melalui Whatshapp mahasiswa. Setelah mahasiswa melakukan wawancara, jawaban peternak langsung dikirim melalui WA atau email untuk ditabulasi. Perilaku peternak sapi potong ditentukan menggunakan Teori Perilaku Terencana (Theory of planned behavior) yang dikembangkan oleh Ajzen (1991) yang merupakan salah satu teori sikap yang banyak diaplikasikan dalam beragam perilaku. Arniati (2009) juga menyatakan bahwa Teori Perilaku Terencana merupakan salah satu model psikologi sosial yang paling sering digunakan untuk meramalkan perilaku dan merupakan prediksi perilaku yang baik karena diseimbangkan oleh niat untuk melaksanakan perilaku. Theory of planned behavior dikhususkan pada perilaku spesifik seseorang dan untuk semua perilaku secara umum. Niat seseorang untuk berperilaku dapat diprediksi oleh tiga hal yaitu sikap terhadap perilaku (attitude toward the behavior), norma subyektif (subjective norm), dan persepsi pengendalian diri (perceived behavioral control). Attitude toward the behavior merupakan keseluruhan evaluasi seseorang mengenai positif atau negatifnya untuk menampilkan suatu perilaku tertentu. Subjective norm merupakan kepercayaan seseorang mengenai tuntutan dari orang lain yang dianggap penting baginya untuk bersedia menampilkan atau tidak menampilkan suatu perilaku tertentu sesuai dengan tuntutan. Perceived behavioral control adalah persepsi seseorang tentang kemampuannya untuk menampilkan suatu perilaku tertentu (Ajzen 1991). Metode penentuan perilaku peternak sapi potong di Era New Normal Covid-19 pada penelitian ini mengacu pada metode penelitian yang digunakan Lestari et al. (2019) dengan modifikasi jumlah pertanyaan dalam questioner sebanyak 25 buah pertanyaan dengan menggunakan lima skala Linker yaitu: 1 = tidak setuju, 2 = kurang setuju, 3 = cukup setuju, $4=$ setuju dan $5=$ sangat setuju (Gozali, 2013). Data dianalisis secara deskriptif dengan menggunakan tabel distribusi frekuensi.

Untuk mengetahui perilaku peternak sapi potong pada peternakan rakyat di Era New Normal Covid-19 di Nusa Tenggara Barat dilakukan perhitungan dengan menggunakan rumus yang mengacu pada asumsi dasar interval dan rentang kelas yang digunakan Lestari et al. (2019). Variabel sikap, norma subyektif dan kontrol perilaku peternak sapi potong diukur dengan rentang kelas. Skor tertinggi $=$ bobot tertinggi $x$ jumlah responden $x$ jumlah pertanyaan. Skor terendah = bobot terendah $\mathrm{x}$ jumlah responden $\mathrm{x}$ jumlah pertanyaan. Rentang kelas = skorter tinggi - skor terendah dibagi jumlah kelas. Berdasarkan nilai tersebut dibuat lima kategori: sangat setuju, setuju, cukup setuju, kurang setuju, dan 
tidaksetuju. Hasil perhitungan ditampilkan pada Tabel 1.

Tabel 1. Perhitungan skor, rentang kelas, dan kategori perilaku peternak sapi potong pada penerapan biosekuriti di Nusa Tenggara Barat*

\begin{tabular}{|c|c|c|c|c|c|c|c|c|c|}
\hline \multirow[b]{2}{*}{ No } & \multirow[b]{2}{*}{ Variabel } & \multirow{2}{*}{$\begin{array}{c}\text { Skor } \\
\text { tertinggi }\end{array}$} & \multirow{2}{*}{$\begin{array}{c}\text { Skor } \\
\text { terendah }\end{array}$} & \multirow{2}{*}{$\begin{array}{c}\text { Rentang } \\
\text { kelas }\end{array}$} & \multicolumn{5}{|c|}{ Kategori } \\
\hline & & & & & $\begin{array}{l}\text { Sangat } \\
\text { setuju }\end{array}$ & Setuju & $\begin{array}{l}\text { Cukup } \\
\text { setuju }\end{array}$ & $\begin{array}{l}\text { Kurang } \\
\text { setuju }\end{array}$ & $\begin{array}{l}\text { Tidak } \\
\text { setuju }\end{array}$ \\
\hline 1 & Sikap & 1.620 & 324 & 295 & $\begin{array}{c}1.364- \\
1.620\end{array}$ & $\begin{array}{l}1.104- \\
1.363\end{array}$ & $\begin{array}{c}844- \\
1.103\end{array}$ & $\begin{array}{c}584- \\
843\end{array}$ & $\begin{array}{c}324- \\
583\end{array}$ \\
\hline 2 & $\begin{array}{l}\text { Norma } \\
\text { subyektif }\end{array}$ & 1.080 & 216. & 173 & $912-1.080$ & $\begin{array}{c}738- \\
911\end{array}$ & 564-737 & $\begin{array}{c}390- \\
563\end{array}$ & $\begin{array}{c}216- \\
389\end{array}$ \\
\hline 3 & $\begin{array}{l}\text { Kontrolp } \\
\text { erilaku }\end{array}$ & 1.800 & 360 & 288 & $\begin{array}{c}1.516- \\
1.800 \\
\end{array}$ & $\begin{array}{l}1.227- \\
1.515 \\
\end{array}$ & $\begin{array}{c}938- \\
1.226 \\
\end{array}$ & $\begin{array}{c}649- \\
937\end{array}$ & $\begin{array}{c}360- \\
648 \\
\end{array}$ \\
\hline 4 & Perilaku & 4.500 & 900 & 720 & $\begin{array}{c}3.784- \\
4.500\end{array}$ & $\begin{array}{c}3.063- \\
3.783\end{array}$ & $\begin{array}{l}2.342- \\
3.062\end{array}$ & $\begin{array}{l}1.621- \\
2.341\end{array}$ & $\begin{array}{l}900- \\
1.620\end{array}$ \\
\hline
\end{tabular}

Catatan : bobot tertinggi $=5$; bobot terendah $=1$; jumlah responden $=36 ;$ Jumlah pertanyaan $($ Sikap $=9$, norma subyektif $=6$, dan kontrol perilaku $=10$ )

* Sumber data : data primer diolah (Mashur, 2011)

\section{HASIL}

\section{Sikap peternak sapi potong terhadap penerapan biosekuriti}

Indikator pertama yang digunakan untuk menentukan perilaku peternak sapi potong pada peternakan rakyat di Nusa Tenggara Barat di Era New Normal Covid-19 terhadap penerapan biosekuriti adalah sikap. Hasil penelitian pernyataan sikap peternak sapi potong pada peternakan rakyat di Provinsi Nusa Tenggara Barat di Era New Normal Covid-19 terhadap penerapan biosekuriti pada peternakan rakyat sapi potong ditampilkan pada Tabel 2. Ada sembilan pernyataan sikap yang diukur untuk menentukan sikap peternak sapi potong terhadap penerapan biosekuriti pada peternakan rakyat di Nusa Tenggara Barat, yaitu:
(1) Penerapan biosekuriti merupakan benteng pertama dalam usaha pencegahan penyakit (One Health); (2) Penerapan biosekuriti mendukung pelaksanaan kesejahteraan hewan (Animal welfare); (3) Penerapan biosekuriti meningkatkan produktivitas ternak sapi (Produktivitas); Penerapan biosekuriti dapat menghemat biaya produksi ternak sapi (Keuntungan Relative); (5) Penerapan biosekuriti pada ternak sapi lebih fleksibel (Fleksibilitas); (6) Penerapan biosekuriti pada ternak sapi hasilnya kelihatan (dilihat dari tidak ada wabah penyakit) sehingga dapat dikomunikasikan dengan peternak lain (Observabilitas); (7) Kehandalan penerapan biosekuriti teruji (Reliability); 
(8) Cara penerapan biosekuriti tidak rumit (Kompleksitas) dan (9) Penerapan biosekuriti membantu mengatasi pencemaran lingkungan (Persepsi lingkungan). Di antara kesembilan pernyataan sikap tersebut yang paling tinggi bobotnya (153) adalah penerapan biosekuriti merupakan benteng pertama dalam usaha pencegahan penyakit (One Health) dan yang paling rendah bobotnya (135) adalah pernyataan bahwa cara penerapan biosekuriti tidak rumit (Kompleksitas).

Tabel 2. Sikap peternak sapi potong terhadap penerapan biosekuriti

\begin{tabular}{|c|c|c|c|c|}
\hline Pernyataan sikap & Skor & Frekuensi & Bobot & Presentase \\
\hline 1. Penerapan biosekuriti merupakan & 5 & 9 & 45 & 29,41 \\
\hline benteng pertama dalam usaha & 4 & 27 & 108 & 70,59 \\
\hline pencegahan penyakit(One Health) & 3 & 0 & 0 & 0 \\
\hline & 2 & 0 & 0 & 0 \\
\hline & 1 & 0 & 0 & 0 \\
\hline Total 1 & & & 153 & 100 \\
\hline 2. Penerapan biosekuriti mendukung & 5 & 6 & 30 & 20 \\
\hline pelaksanaan kesejahteraan hewan & 4 & 30 & 120 & 80 \\
\hline (Animal welfare) & 3 & 0 & 0 & 0 \\
\hline & 2 & 0 & 0 & 0 \\
\hline & 1 & 0 & 0 & 0 \\
\hline Total 2 & & & 150 & 100 \\
\hline 3. Penerapan biosekuriti meningkatkan & 5 & 7 & 35 & 23,18 \\
\hline produktivitas ternak sapi (Produktivitas) & 4 & 29 & 116 & 76,82 \\
\hline & 3 & 0 & 0 & 0 \\
\hline & 2 & 0 & 0 & 0 \\
\hline & 1 & 0 & 0 & 0 \\
\hline Total 3 & & & 151 & 100 \\
\hline 4. Penerapan biosekuriti dapat menghemat & 5 & 5 & 25 & 17,61 \\
\hline biaya produksi ternak sapi (Keuntungan & 4 & 25 & 100 & 70,42 \\
\hline Relative) & 3 & 5 & 15 & 10,56 \\
\hline & 2 & 1 & 2 & 1,41 \\
\hline & 1 & 0 & 0 & 0 \\
\hline Total 4 & & & 142 & 100 \\
\hline 5. Penerapan biosekuriti pada ternak sapi & 5 & 2 & 10 & 7,14 \\
\hline lebih fleksibel (Fleksibilitas) & 4 & 28 & 112 & 85,71 \\
\hline & 3 & 6 & 18 & 7,15 \\
\hline & 2 & 0 & 0 & 0 \\
\hline & 1 & 0 & 0 & 0 \\
\hline Total 5 & & & 140 & 100 \\
\hline 6. Penerapan biosekuriti pada ternak sapi & 5 & 13 & 65 & 43,62 \\
\hline
\end{tabular}


hasilnya kelihatan (dilihat dari tidak ada wabah penyakit) sehingga dapat

dikomunikasikan dengan peternak lain

(Observabilitas)

Total 6

7. Kehandalan penerapan biosekuriti teruji (Reliability)

Total 7

8. Cara penerapan biosekuriti tidak rumit (Kompleksitas)

\section{Total 8}

9. Penerapan biosekuriti membantu mengatasi pencemaran lingkungan (Persepsi lingkungan)

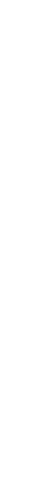

3

4
3
2
1
5
4
3
2
1

21
2
0
0

$\begin{array}{cc}84 & 56,37 \\ 6 & 0,01 \\ 0 & 0 \\ 0 & 0 \\ \mathbf{1 4 9} & 100\end{array}$

3
24
8
1
0

15

10,95

$96 \quad 70,07$

$24 \quad 17,52$

$2 \quad 1,46$

$0 \quad 0$

$137 \quad 100$

$\begin{array}{cccc}5 & 3 & 15 & 11,11 \\ 4 & 23 & 92 & 68,15\end{array}$

$\begin{array}{cccc}3 & 23 & 92 & 68,15 \\ 3 & 8 & 24 & 17,78\end{array}$

$\begin{array}{cccc}3 & 8 & 24 & 17,78 \\ 2 & 2 & 4 & 2,96\end{array}$

10000

$135 \quad 100$

$\begin{array}{llll}5 & 10 & 50 & 35,21\end{array}$

$\begin{array}{llll}4 & 21 & 84 & 59,15\end{array}$

$\begin{array}{llll}3 & 1 & 3 & 2.11\end{array}$

$\begin{array}{llll}2 & 1 & 2 & 1,41\end{array}$

$\begin{array}{llll}1 & 3 & 3 & 2,12\end{array}$

Total 9

142

\section{Total sikap}

Berdasarkan nilai total sikap peternak sapi potong terhadap pelaksanaan biosekuriti seperti ditampilkan pada Tabel 2 dengan Sembilan pertanyaan pada 36 orang peternak sapi potong sebagai responden menggunakan lima kategori skor maka diperoleh bobot sebesar 1.299. Berdasarkan data pada Tabel 1 dan Tabel 2, sikap peternak sapi potong terhadap penerapan biosekuriti berada pada kategori setuju dengan interval bobot $1.104-1.363$.

\section{Norma subyektif peternak sapi potong terhadap penerapan biosekuriti \\ Indikator kedua dalam} menentukan penerapan biosekuriti pada peternakan rakyat sapi potong di Era New Normal Covid-19 di Nusa Tenggara Barat adalah norma subyektif. Hasil penelitian berdasarkan pernyataan norma subyektif peternak sapi potong pada peternakanrakyat di Provinsi Nusa Tenggara Barat di Era New Normal Covid-19 terhadap penerapan biosekuriti ditampilkan pada Tabel 3. Ada enam pernyataan 
norma subyektif yang digunakan untuk menentukan penerapan biosekuriti pada peternakan rakyat sapi potong, yaitu; (1) Peternak sapi hanya akan menerapkan biosekuriti jika didukung atau dianjurkan oleh tokoh agama (informal leader); (2) Peternak sapi hanya akan menerapkan biosekuriti jika didukung atau dianjurkan oleh tokoh masyarakat; (3) Peternak sapi hanya akan menerapkan biosekuriti jika didukung atau dianjurkan oleh pemerintah; (4) Peternak sapi hanya akan menerapkan biosekuriti jika didukung atau dianjurkan oleh petugas dan penyuluh di lapangan; (5) Peternak sapi hanya akan menerapkan biosekuriti jika didukung atau dianjurkan oleh keluarganya dan (6) Peternak sapi hanya akan menerapkan biosekuriti jika didukung atau dianjurkan oleh peternak lain atau kelompok tani. Di antara keenam pernyataan norma subyektif tersebut yang paling tinggi bobotnya (129) adalah peternak sapi hanya akan menerapkan biosekuriti jika didukung atau dianjurkan oleh petugas dan penyuluh di lapangan dan yang paling rendah (92) adalah peternak sapi potong hanya akan menerapkan biosekuriti apabila didukung atau dianjurkan oleh tokoh agama (informal leader).

Tabel 3. Norma subyektif peternak sapi potong terhadap biosekuriti

\begin{tabular}{lcccc}
\hline \multicolumn{1}{c}{ Pernyataan } & Skor & Frekuensi & Bobot & Presentase \\
\hline 1. Peternak sapi hanya akan menerapkan & 5 & 2 & 10 & 10,87 \\
biosekuriti jika didukung atau & 4 & 4 & 16 & 17,39 \\
dianjurkan oleh tokoh agama & 3 & 10 & 30 & 32,61 \\
(informal leader) & 2 & 16 & 32 & 34,78 \\
& 1 & 4 & 4 & 4,35 \\
Total 1 & & 36 & $\mathbf{9 2}$ & 100 \\
2. Peternak sapi hanya akan menerapkan & 5 & 2 & 10 & 9,17 \\
biosekuriti jika didukung atau & 4 & 12 & 48 & 44,04 \\
dianjurkan oleh tokoh masyarakat & 3 & 10 & 30 & 27,52 \\
& 2 & 9 & 18 & 16,52 \\
$\quad$ Total 2 & 1 & 3 & 3 & 2,75 \\
Teternak sapi hanya akan menerapkan & 5 & 36 & $\mathbf{1 0 9}$ & 100 \\
biosekuriti jika didukung atau & 4 & 13 & 15 & 12,93 \\
dianjurkan oleh pemerintah & 3 & 10 & 32 & 44,83 \\
$\quad$ & 2 & 9 & 18 & 25,87 \\
$\quad$ Total 3 & 1 & 1 & 1 & 0.85 \\
& & 36 & $\mathbf{1 1 6}$ & 100 \\
& 5 & 7 & 35 & 27,13 \\
Peternak sapi hanya akan menerapkan & 5 & 15 & 60 & 46,51
\end{tabular}




dianjurkan oleh petugas dan
penyuluh di lapangan

Total 4

5. Peternak sapi hanya akan menerapkan biosekuriti jika didukung atau dianjurkan oleh keluarganya

\section{Total 5}

6. Peternak sapi hanya akan menerapkan biosekuriti jika didukung atau dianjurkan oleh peternak lain atau kelompok tani

Total 6

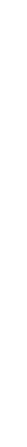

3
2
1

$4 \quad 12$

$3 \quad 8$

213

12

$7 \quad 21$

16,27

$\begin{array}{lll}6 & 12 & 9,30\end{array}$

$\begin{array}{lll}1 & 1 & 0,79\end{array}$

$\begin{array}{lll}36 & \mathbf{1 2 9} & 100\end{array}$

$1 \quad 5 \quad 4,76$

$12 \quad 48 \quad 45,71$

$\begin{array}{lll}8 & 24 & 22,86\end{array}$

$13 \quad 26 \quad 24,76$

$\begin{array}{lll}2 & 2 & 1,91\end{array}$

$36 \quad 105 \quad 100$

$3 \quad 15 \quad 12,50$

$18 \quad 72 \quad 60,00$

$5 \quad 15 \quad 12,50$

$8 \quad 16 \quad 13,33$

$\begin{array}{lll}2 & 2 & 1,67\end{array}$

$\begin{array}{lll}36 & \mathbf{1 2 0} & 100\end{array}$

Berdasarkan nilai total norma subyektif peternak sapi potong terhadap pelaksanaan biosekuriti seperti ditampilkan pada Tabel 3 dengan enam pertanyaan pada 36 orang peternak sapi potong sebagai responden menggunakan lima kategori skor maka diperoleh bobot sebesar 671 . Berdasarkan data pada Tabel 1 dan Tabel 3, norma subyektif peternak sapi potong terhadap pelaksanaan biosekuriti berada pada kategori cukup setuju dengan interval bobot 564-737.

\section{Kontrol perilaku peternak sapi potong terhadap penerapan biosekuriti}

Indikator ketiga dalam menentukan penerapan biosekuriti pada peternakan rakyat sapi potong di Era New Normal Covid-19 di Nusa Tenggara Barat adalah kontrol perilaku. Hasil penelitian menunjukkan bahwa pernyataan kontrol perilaku peternak sapi potong pada peternakan rakyat di Provinsi Nusa Tenggara Barat di Era New Normal Covid-19 terhadap penerapan biosekuriti, seperti ditampilkan pada Tabel 4. Ada 10 pernyataan kontrolperilaku yang digunakan untuk menentukan penerapan biosekuriti pada peternakan rakyat sapi potong, yaitu: (1) Penerapan biosekuriti membutuhkan waktu lama mulai mempersiapkan sampai dengan menggunakannya (time), (2) Peternak sapi sudah terbiasa menerapkan biosekuriti (habit ), (3) Penerapan biosekuriti dapat diujicobakan pada skala usaha ternak sapi yang kecil (triabilitas), (4) Penerapan biosekuriti sesuai dengan kebutuhan peternak sapi 
(compatibility), (5) Dari pengalaman masa lalu, penerapan biosekuriti tidak memberikan hasil yang memuaskan (prior Implementation), (6) Penerapan biosekuriti pada sapi Bali lebih berisiko dibanding tanpa biosekuriti (risk), (7) Kurangnya tenaga kerja untuk penerapan biosekuriti (resource), (8) Kurangnya pengetahuan dan keterampilan untuk menerapkan biosekuriti (training), (9) Kurangnya informasi mengenai biosekuriti (information), dan (10) Kurangnya pembinaan dan pendampingan oleh petugas dan penyuluh pertanian di lapangan (extension). Di antara ke 10 pernyataan kontrol perilaku tersebut yang paling tinggi bobotnya (149) adalah penerapan biosekuriti pada sapi Bali lebih berisiko dibanding tanpa biosekuriti (risk) dan pernyataan yang paling rendah bobotnya (122) adalah kurangnya tenaga kerja untuk penerapan biosekuriti (resource).

Tabel 4. Kontrol perilaku peternak sapi potong terhadap penerapam biosekuriti

\begin{tabular}{|c|c|c|c|c|c|}
\hline \multicolumn{2}{|r|}{ Pernyataan } & Skor & Frekuensi & Bobot & Presentase \\
\hline \multirow[t]{6}{*}{1.} & Penerapan biosekuriti membutuhkan & 5 & 5 & 25 & 19,38 \\
\hline & waktu lama mulai mempersiapkan & 4 & 16 & 64 & 49,61 \\
\hline & sampai dengan menggunakannya & 3 & 11 & 33 & 25,58 \\
\hline & (Time) & 2 & 3 & 6 & 4,65 \\
\hline & & 1 & 1 & 1 & 0,78 \\
\hline & Total 1 & & 36 & 129 & 100 \\
\hline \multirow[t]{6}{*}{2.} & Peternak sapi sudah terbiasa & 5 & 3 & 15 & 11,19 \\
\hline & menerapkan biosekuriti (Habit) & 4 & 21 & 84 & 62,69 \\
\hline & & 3 & 11 & 33 & 24,63 \\
\hline & & 2 & 1 & 2 & 1,49 \\
\hline & & 1 & 0 & 0 & 0 \\
\hline & Total 2 & & 36 & 134 & 100 \\
\hline \multirow[t]{6}{*}{3.} & Penerapan biosekuriti dapat & 5 & 4 & 20 & 14,39 \\
\hline & diujicobakan pada skala usaha ternak & 4 & 24 & 96 & 69,06 \\
\hline & sapi yang kecil (Triabilitas) & 3 & 7 & 21 & 15,11 \\
\hline & & 2 & 1 & 2 & 1,44 \\
\hline & & 1 & 0 & 0 & 0 \\
\hline & Total 3 & & 36 & 139 & 100 \\
\hline \multirow[t]{6}{*}{4.} & Penerapan biosekuriti sesuai dengan & 5 & 3 & 15 & 10,64 \\
\hline & kebutuhan peternak sapi & 4 & 28 & 112 & 79,43 \\
\hline & (Compatibility) & 3 & 4 & 12 & 8,51 \\
\hline & & 2 & 1 & 2 & 1,42 \\
\hline & & 1 & 0 & 0 & 100 \\
\hline & Total 4 & & 36 & 141 & 100 \\
\hline & Dari pengalaman masa lalu, & 5 & 2 & 10 & 7,14 \\
\hline & penerapan biosekuriti tidak & 4 & 28 & 112 & 85,71 \\
\hline
\end{tabular}


Mashur. MKH (2022). 1-17

DOI: $\underline{10.20473 / \mathrm{mkh} . v 33 i 1.2022 .1-17}$

memberikan hasil yang memuaskan

(Prior Implementation)

3

Total 5

1

6. Penerapan biosekuriti pada sapi Bali

lebih berisiko dibanding tanpa

biosekuriti (risk)

Total 6

7. Kurangnya tenaga kerja untuk penerapan biosekuriti (resource)

Total 7

8. Kurangnya pengetahuan dan keterampilan untuk menerapkan biosekuriti (training)

Total 8

9. Kurangnya informasi mengenai biosekuriti (information)

Total 9

10. Kurangnya pembinaan dan pendampingan oleh petugas dan penyuluh pertanian di lapangan (extension)

5

4

3

2

1

\section{5}

4

3

2

1

36

5

4

3

2

1

36

$5 \quad 5$

420

33

23

1

36

53

420

35

25

13

$$
18
$$

0

$$
0
$$

140

65

84

$$
6
$$

0

0

149

15

15

76

18

10

3

122

25

84

9

9

8

3

129

25

80

9

6

6
5

125

15

80

15

10

3

123
7,15

0

0

100

43,62

56,37

0,01

0

0

100

12,29

62,29

14,75

8,19

2,48

100

19,38

65,12

6,98

6,20

2,32

100

20,00

64,00

7,20

4,80

4,00

100

12,19

65,04

12,19

8,13

2,45

100

Berdasarkan nilai total kontrol

pertanyaan pada 36 orang peternak sapi perilaku peternak sapi potong terhadap penerapan biosekuriti seperti potong sebagai responden ditampilkan pada Tabel 4 dengan 10 menggunakan lima kategori skor maka diperoleh bobot sebesar 1.331. 
Mashur. MKH (2022). 1-17

DOI: $\underline{10.20473 / \mathrm{mkh} . v 33 i 1.2022 .1-17}$

Berdasarkan data pada Tabel 1 dan Tabel 4, kontrol perilaku peternak sapi potong terhadap penerapan biosekuriti berada pada kategori setuju dengan interval bobot 1.227 - 1.515 .

\section{Perilaku peternak sapi potong di Era New Normal Covid-19 terhadap penerapan biosekuriti pada peternakan rakyat di Nusa Tenggara Barat}

Berdasarkan hasil penelitian pada Tabel 2, 3 dan 4 menunjukkan bahwa nilai total pernyataan sikap, norma subyektif dan kontrol perilaku peternak sapi potong pada peternakan rakyat di Era New Normal Covid-19 di Nusa Tenggara Barat terhadap penerapan biosekuriti maka diperoleh bobot sebesar 3.301. Dengan demikian, pernyataan sikap, norma subyektif dan kontrol perilaku peternak sapi potong terhadap penerapan biosekuriti pada peternakan rakyat di Era New Normal Covid-19 di Nusa Tenggara Barat berada pada kategori setuju dengan interval bobot 3.063- 3.783, seperti ditampilkan pada Tabel 5.

Tabel 5. Perilaku peternak sapi potong terhadap penerapan biosekuriti pada peternakan rakyat di Era New Normal Covid-19 di Nusa Tenggara Barat

\begin{tabular}{lcc}
\hline \multicolumn{1}{c}{ Variabel pengukuran } & Bobot & Kategori \\
\hline Sikap & 1.299 & setuju \\
Norma subyektif & 671 & Cukup setuju \\
Kontrol perilaku & 1.331 & setuju \\
Perilaku & 3.301 & setuju \\
\hline
\end{tabular}

\section{PEMBAHASAN}

1. Sikap peternak sapi potong terhadap penerapan biosekuriti

Berdasarkan hasil penelitian

pada Tabel 2 menunjukkan bahwa sikap peternak sapi potong pada peternakan rakyat di Era New Normal Covid-19 terhadap penerapan biosekuriti berada pada kategori setuju dengan interval bobot $1.104-1.363$. Hal ini disebabkan karena penerapan biosekuriti merupakan benteng pertama dalam usaha pencegahan penyakit, meningkatkan produktivitas ternak sapi, mendukung pelaksanaan kesejahteraan hewan dan hasilnya dapat dilihat dari tidak ada wabah penyakit sehingga dapat dikomunikasikan dengan peternak lain sesuai dengan pencegahan dan pengendalian patogen endemik di dalam dan diantara peternakan seringkali tergantung pada penerapan praktik manajemen yang terbaik. Peternak tidak mengadopsi langkah langkah yang direkomendasikan atau tidak mendaftar dalam program 
pengendalian penyakit secara sukarela, artinya peternak memerlukan penyuluhan (Ritter et al., 2017). Metode penyuluhan yang paling efektif apabila jumlah sasaran penyuluhan sangat banyak atau masal maka pertemuan umum merupakan metode penyuluhan yang paling efektif (Mashur, 2017; Mashur et al., 2018). Jumlah sasaran penyuluhan berupa kelompok $(\leq 20$ orang) maka diskusi kelompok merupakan metode penyuluhan yang paling efektif. Apabila sasaran penyuluhan secara perorangan, maka kunjungan rumah ke rumah merupakan metode penyuluhan yang paling efektif. Jika metode penyuluhan yang paling efektif dapat diterapkan diharapkan dapat meningkatkan pengetahuan, keterampilan dan perubahan perilaku peternak rakyat dalam mencegah penyakit, sehingga bahaya penyakit dapat diminimalisir. Program sosialisasi telah meningkatkan pengetahuan dan praktek biosekuriti peternak unggas. Penyuluhan yang disampaikan oleh kader nampak lebih efektif dibandingkan dengan cara lain, yang ditandai oleh persentasi keterlibatan peternak yang lebih banyak dibandingkan media lainnya (llyas, et al., 2014).

Menurut Brennan et al. (2016), praktek pencegahan dan pengendalian penyakit sering disoroti sebagai hal penting untuk memastikan kesehatan dan kesejahteraan hewan ternak. Richens et al. (2018) menyebutkan bahwa peternak umumnya termasuk ke dalam salah satu dari dua kategori, yaitu mereka yang tidak menerapkan langkah-langkah biosekuriti tanpa niat untuk melakukannya di masa depan, dan mereka yang melakukan langkahlangkah biosekuriti untuk beberapa waktu. Para peternak merasa bahwa biosekuriti meningkatkan kesehatan dan kesejahteraan ternak, tetapi juga merasa bahwa penyakit tidak bisa dihindari. Lebih banyak peternak setuju dengan pernyataan yang berkaitan dengan kemampuan mereka untuk mengendalikan, dibandingkan dengan pencegahan penyakit.

\section{Norma subyektif peternak sapi potong terhadap penerapan biosekuriti}

Berdasarkan hasil penelitian pada Tabel 3 menunjukkan bahwa norma subyektif peternak sapi potong pada peternakan rakyat di Era New Normal Covid-19 terhadap penerapan biosekuriti berada pada kategori cukup setuju dengan interval bobot 564 - 737, Hal ini disebabkan karena peternak sapi potong hanya akan menerapkan biosekuriti jika didukung atau dianjurkan oleh tokoh agama, peternak sapi hanya akan menerapkan biosekuriti jika didukung atau dianjurkan oleh keluarganya dan peternak sapi hanya akan menerapkan biosekuriti jika didukung atau dianjurkan oleh tokoh masyarakat. Hasil penelitian ini berbeda dengan hasil penelitian Lestari et al. (2019) menunjukkan bahwa perilaku peternak 
sapi potong terhadap pelaksanaan biosekuriti berdasarkan norma subyektif termasuk kategori kurang setuju dengan total bobot 249 (berada diantara rentang $200-280$ ). Berdasarkan persentase jawaban tertinggi dari setiap pertanyaan, peternak sapi potong setuju melaksanakan biosekuriti apabila didukung / dianjurkan oleh keluarganya $(46,67 \%)$, Hal ini berbeda dengan penelitian yang dilakukan oleh Lestari et al. (2018) di Kecamatan Lamasi Kabupaten Luwu yang menunjukkan bahwa peternak sapi potong setuju melaksanakan biosekuriti apabila didukung oleh tokoh masyarakat, hal ini berbeda karena karakteristik responden di Kabupaten Soppeng menjunjung tinggi asas kekeluargaan, sedangkan di Kabupaten Luwu, mayoritas responden adalah transmigran berasal dari Jawa Timur yang menganut asas panutan yaitu tokoh masyarakat.

\section{Kontrol perilaku peternak sapi potong terhadap penerapan biosekuriti}

Berdasarkan hasil penelitian

pada Tabel 4 menunjukkan bahwa kontrol perilaku peternak sapi potong pada peternakan rakyat di Era New Normal Covid-19 terhadap penerapan biosekuriti berada pada kategori setuju dengan interval bobot $1.227-1.515$, hal ini disebabkan karena penerapan biosekuriti pada sapi Bali lebih berisiko dibanding tanpa biosekuriti, penerapan biosekuriti sesuai dengan kebutuhan peternak sapi dan dari pengalaman masa lalu, penerapan biosekuriti tidak memberikan hasil yang memuaskan. Hasil penelitian ini sesuai dengan hasil penelitian Lestari et al. (2019) menunjukkan bahwa perilaku peternak sapi potong terhadap pelaksanaan biosekuriti berdasarkan kontrol perilaku termasuk kategori setuju dengan bobot 665 (berada pada rentang 630 - 810), Hal ini berbeda dengan pendapat Lestari et al. (2018), yang menyatakan bahwa kontrol perilaku peternak sapi potong di Kecamatan Lamasi Kabupaten Luwu menunjukkan $56,57 \%$ kurang setuju terhadap penerapan biosekuruti. Berdasarkan persentase tertinggi untuk setiap pertanyaan yang diajukan, maka pelaksanaan biosekuriti sesuai dengan kebutuhan peternak sapi $(90,0 \%)$. Ada wabah penyakit atau tidak ada wabah penyakit, biosekuriti harus dilaksanakan di setiap peternakan sapi potong. Valergakis et al. (2018) menyatakan bahwa langkah - langkah biosekuriti umum harus diberlakukan di peternakan apapun terlepas dari kelemahan spesifik apapun.

4. Perilaku peternak sapi potong di Era New Normal Covid-19 terhadap penerapan biosekuriti pada peternakan rakyat di Nusa Tenggara Barat

Berdasarkan hasil penelitian pada Tabel 2, 3, dan 4 menunjukkan bahwa perilaku peternak sapi potong 
pada peternakan rakyat di Era New Normal Covid-19 terhadap penerapan biosekuriti berada pada kategori setuju dengan interval bobot 3.063 - 3.783, hal ini sesuai dengan hasil penelitian Lestari et al. (2019) bahwa secara keseluruhan perilaku peternak sapi potong terhadap pelaksanaan biosekuriti berada pada ketegori setuju dengan bobot 1.539 (berada pada rentang 1.400 - 1.800). Hasil penelitian ini juga sesuai dengan pendapat Ajzen (2002) yang menyatakan bahwa semakin baik sikap terhadap perilaku dan norma subyektif, dan semakin besar kontrol perilaku yang dirasakan, semakin kuat niat seseorang untuk melakukan perilaku tersebut. Tingkat kontrol aktual yang cukup atas perilaku orang diharapkan untuk melaksanakan niat mereka ketika ada kesempatan.

\section{KESIMPULAN}

Berdasarkan hasil penelitian penerapan biosekuriti pada peternakan rakyat sapi potongdi Era New Normal Covid-19 di Provinsi Nusa Tenggara Barat, dapat disimpulkan bahwa dari segi sikap peternak sapi potong berada pada kategori setuju, dari segi norma subyektif berada pada kategori cukup setuju, dan dari segi kontrol perilaku berada pada kategori setuju, dengan demikian, perilaku peternak sapi potong pada peternakan rakyat di Nusa Tenggara Barat berada pada kategori setuju dengan penerapan biosekuriti pada peternakan rakyat sapi potong di Era New Normal Covid-19.

\section{UCAPAN TERIMA KASIH}

Ucapan terima kasih disampaikan kepada mahasiswa semester 2 Fakultas Kedokteran Hewan Universitas Pendidikan Mandalika Mataram yang mengambil Mata Kuliah Manajemen Penyakit Sapi Bali Tahun 2020/2021 yang telah bersedia sebagai enemurator untuk mengumpulkan data mewawancarai peternak sapi pada peternakan rakyat di desanya masingmasing. Ucapan terimakasih juga kami sampaikan kepada Dekan Fakultas Kedokteran Hewan dan Kepala LPPM Undikma yang telah memberikan izin melakukan penelitian dengan biaya mandiri.

\section{DAFTAR PUSTAKA}

Ajzen, I. 1991. The theory of planned behavior. Organizational Behavior and Human Decision Processes. 50 : 179-211. doi: 10.1016/0749-5978(91)90020-T

Ajzen, I. 2002. Perceived behavioral control, self-efficacy, locus of control, and the theory of planned behavior. J Appl Soc Psychol. 32:665-683.

Ajzen, I. 2006. Attitude, Personality, and Behavior. 2nd Edition. Berkshire, UK Open University PressMcGraw Hill Education 
Arniati. 2009. Peran Theory of Planned Behavior terhadap ketaatan wajib pajak. Seminar Nasional Perpajakan II. Universitas Trunojoyo

Bonanno, G.A., M. Westphal and A.D. Mancini. 2011. Resilience to loss and potential trauma. Annu Rev Clin Psychol. 2011; 7 : 511-35. doi: 10.1146/annurev-clinpsy032210-104526.PMID:21091190.

Brennan, M.L., N. Wright, W. Wapenaar, S. Jarratt, P.H. West, I.F. Richens, J. Kaler, H. Buchanan, J.N. Huxley, H.M. O'Connor. 2016. Exploring attitudes and beliefs towards implementing cattle disease prevention and control measures: A qualitative study with dairy farmers in Great Britain. Animals. 6:61.

Direktorat Jenderal Peternakan dan Kesehatan Hewan. 2014. Peraturan Pemerintah Republik Indonesia Nomor 47 Tahun 2014 tentang Pengendalian dan Penanggulangan Penyakit Hewan [Internet].

[Diaksestanggal 4 Juni 2019]. Tersedia dari: ditjennak.pertanian.go.id/userfil es/regulasi/fe6d47d314bb6aec44 7ff4e7a9157a31.pdf.

Ghozali, I. 2013. Aplikasi Analisis Multivariate Dengan Program IBM SPSS 2.0. Semarang: Badan PenerbitUndip. ISBN: 979.704.300.2.
Ilham, N. dan G. Haryanto. 2020. Dampak Pandemi Covid-19 pada produksi dan kapasitas peternak: Perspektif Adaptasi dan Resiliensi Sosial Ekonomi Pertanian.

https://pse.litbang.pertanian.go. id/ind/pdffiles/10-BBRC-2020III-1-2-ILH.pdf

Ilyas, A.Z., Etih S, Denny W.L, Yusuf R, Chaerul B, Agus S, dan Patrick H.2014. Program sosialisasi dalam upaya peningkatan pengetahuan dan praktek biosekuriti peternak ayam sektor 4 di Kabupaten Subang. Prosiding Konferensi Ilmiah Veteriner Nasional (KIVNAS) ke-13 Palembang, 23-26 November 2014.

Lestari, V.S., D.P. Rahardja, P. Mappigau, S.T. Rohani dan S.N. Sirajuddin. 2018. Perilaku peternak sapi potong terhadap penerapan bio sekuriti berdasarkan norma subyektif. Buku Abstrak Seminar Nasional Politani Pertanian Pangkep. 24 September 2018, Makassar.

Lestari, V.S., D.P. Rahardja, P. Mappigau, S.T. Rohani dan Sirajuddin SN. 2019. Beef cattle farmer's attitude to biosecurity. Proceeding IOP Conference Series: Earth and Environmental Science 260 (2019) 011002, Second International Conference on Agriculture, Environment and Food Security. October 24, Medan. 
Mashur. 2017. The Effective Extension Methods for Prevention of Anthrax Diseases on Smallholders Farming in Supproting West Nusa Tenggara Province as A World Halal Tourism Destination. The 2nd International Conference on Science and Technology 2017 "Joint International Conference on Science and Technology in the Tropic"

Mashur., Kholik, Munawarah and D.A. Candra. 2018. The Most Effective Extension Methods to Prevent Influenza Avian Disease on Small Holders Farming in Tourism Destination Nusa Tenggara Barat. 1' ${ }^{\text {st }}$ ICWBB 2018.

Mashur., Y. Suhubdy, Kholik, D. Oktaviana, K. Tirtasari dan S. Nurus. 2020. Penerapan Manajemen Kesehatan Kandang Kolektif Sapi Potong Pada Peternakan Rakyat Di Pulau Lombok Provinsi Nusa Tenggara Barat. Prosiding Webinar Nasional Sapi Kerbau IV. Universitas Andalas Padang. 21 Oktober 2020. ISBN: 978-6237763-73-4.

Mashur. 2021. Strategy for Improving the Management of Feed and Drinking Water for Smallholders Livestock Based on Sustainability Status in Lombok Island, Indonesia. Current Research in Agriculture and Veterinary
Sciences Vol. 3, 5267https://doi.org/10.9734/bpi/ cravs/v3/8097D

Richens, I.F., J. Houdmont, W. Wapenaar and O. Shortall. 2018. Application of multiple behavior change models to identify determinants of farmer's biosecurity attitudes and behaviours. Preventive Veterinary Medicine. 155.

Ritter, C., J. Jansen, S. Roche, D.F. Kelton, C.L. Adams, K.O. Ron, J. Erskine, G. Benedictus, T.J.G..M Lamand H.W. Barkema. 2017. Invited review: Determinants of farmer's adoption of management-based strategies for infectious disease prevention and control. J Dairy Sci.100:3329-3347. Valergakis, G., G. Arsenos and G. Oikonomou. 2018. Biosecurity measures on cattle farms. JHellenic Vet Medic Society. 59:922. 